ably long, as also the antennæ. These are not new formations, but simply modifications apparently, by use or disuse of organs present in the other species. The aberrant myriopod and Stagobius are paralleled by the blind fish, an animal so difficult to classify, and so evidently adapted for its abode in endless darkness. And as an additional proof of the view here taken that these cave animals are modified from more or less allied species existing outside of the caves, we have the case of the crawfish, whose eyes (like those of the mole), are larger in the young than in the adult, indicating its descent from a species endowed with the faculty of sight, while in the adult the appendages are modified as tactile organs so as to make up for its loss of eyesight, in order that it may still take its prey.

We thus see that these cave animals are modified in various ways, some being blind, others very hairy, others with long appendages. All are not modified in the same way in homologous organs ; another argument in proof of their descent from ancestors whose habits varied as those of their out-of-door allies do at present. Had they been specially created for subterranean life, we should have expected a much greater uniformity in the organs adapting them to a cave life than we actually find to be the case.

Another fact of interest in this connection is the circum. stance that these cave species breed slowly, being remarkably poor in individuals; they are nearly all, except the wingless grasshoppers, extremely rare. Did they breed as numerously as their allies in the outer world, the whole race would probably starve, as the supply of food even for those which do live is wonderfully limited.

It is now known that animals inhabiting the abysses of the sea are often highly coloured: light must penetrate there, for we know that were the darkness total they would be colourless like the cave insects.

In view of the many important questions which arise in relation to cave animals, and which have been too imperfectly discussed here, we trust naturalists the world over will be led to explore caves with new zeal, and record their discoveries with minuteness, and the greatest possible regard to exactness. The caves of the West Indian Islands should first of all be carefully explored. Also those of Brazil, those of the East Indies, and of Africa, while fresh and more extended explorations of our own Mammoth Cave should be made, perhaps by a commission acting under Government or State authority, in order that the most ample facilities may be afforded by the parties owning the cave.

A. S. PACKARD

\section{PROPOSED GRAND AQUARIUM FOR MANCHESTER}

THE Manchester Examiner and Times of April 2 gives a long account of a Grand Marine Aquarium which it is proposed to build at Manchester, and which shows the interest which is felt in scientific studies in the northern capital. From this article we have made the following extracts, as showing the complete scale upon which everything is proposed to be carried out.

The funds are to be raised by a company started under the superintendence of a number of gentlemen resident in the city who are interested in marine zoology, and desire to promote scientific education in all its branches. The building will contain all the recent improvements shown to be necessary at the Crystal Palace and Brighton Aquaria, and will be rectangular in shape, I $0 \mathrm{ft}$ long and $70 \mathrm{ft}$. wide. This space will be divided into two side galleries, each $120 \mathrm{ft}$. long and $\mathrm{I} 5 \mathrm{ft}$. wide, separated from the central saloon by a light screen. Running along one side of each of these galleries will be a series of tanks, about eighty in number, forty in each gallery, varying in capacity from 300 to 3,000 gallons, and the roofs will be so arranged that the light will pass through the water at an angle of about forty-five degrees to the spectators, thus rendering distinctly visible the living inhabitants and plants contained in the grotto-like tanks. The grand saloon will be also $120 \mathrm{ft}$. long by $40 \mathrm{ft}$. wide, supporting on light iron columns an open panelled roof. All the windows will be so arranged as to admit only the exact quantity of light required, as it is found that an excess of light acts upon the higher marine plants and animals in a manner directly contrary to its action upon terrestrial life. It blanches them in a similar manner as ordinary plants are blanched by being earthed up. The most brilliant coloured marine plants are those which live in comparative darkness. The grand saloon will contain two tanks - the largest that have yet been constructed-one at each end of the room, $30 \mathrm{ft}$. long, Io ft. wide, and $8 \mathrm{ft}$. deep, capable of containing each I 5,000 gallons of water, and in which the largest specimens of fish found in the British seas will find ample room to display themselves. These tanks will have also a polished plate-glass frontage of great strength, through which the animals can be well seen.

In order to accommodate the inhabitants of what is called the littoral zone round our coasts, a series of shallow tanks, varying in capacity from 20 to 200 gallons, will be erected, in which the animals can be seen either from the surface of the water or through the transparent fronts, and by an ingenious contrivance the supply of water will be so regulated as to afford in every respect tidal currents. Besides these there will be other tanks at the back of the exhibition tanks for reserve stocks, and in the basement cisterns to hold a reserve supply of 60,000 gallons of sea water.

Such are the contemplated arrangements for marine, animal, and vegetable life ; but in addition to these the inhabitants of our brooks, ponds, \&c., will not be forgotten, and a series of table aquaria will be provided : while the larger inhabitants of our rivers and lakes will swim in an ever-flowing river and pond supplied by fountains, and placed in the centre of the grand saloon. Such is a brief description of the proposed Manchester Grand Aquarium, which, it is hoped, will both be a success in a scientific, as well as a pecuniary point of view. Mr. B. Hooper, a well-known naturalist, has been engaged as curator of the Aquarium. A site for the Aquarium has been obtained in the vicinity of the Alexandra Park, and it is proposed to open it on Saturdays and Mondays at an admission fee of $\mathrm{I} d$.; on Tuesdays, Wednesdays, and Thursdays, at $6 d$.; and on Friday, which will be a students' day, at $I s$.

\section{NOTES}

The following lectures in Natural Sciences will be delivered in Trinity, St. John's, and Sidney Sussex Colleges, Cambridge, during Easter Term, 1872 :- "On Light and Heat"'(for the natural sciences tripos), by Mr. Trotter, Trinity College; Mondays, Wednesdays, and Fridays, at ro, commencing Wednesday, April $I_{7}$. "On Heat" (for the special examination for the ordinary degree), by Mr. Trotter, Trinity College; Tuesdays, Thursdays, Saturdays, at II, commencing Tuesday, April x6. "On Chemistry," by Mr. Main, St. John's College ; Mondays, Wednesdays, Fridays, at 12 , in St. John's College Laboratory, commencing Friday, April 19. Instruction in Practical Chemistry will also be given. Attendance on these lectures is recognised by the University for the certificate required by medical students previous to admission for the examination for the degree of M.B. "On Palæontology" (the Mollusca), by Mr. Bonney, St. John's College; Wednesdays and Fridays, at 9, commencing Friday, April 19. "On Geology" (for the natural sciences tripos. Stratigraphical Geology), by Mr. Bonney, St. John's College; 'lussdays, Thursdays, and Saturdays, at ro, commencing Thursday, April 18. There will be excursions every Saturday. "Elementary Geology" (for the special examination); Wednesdays 